\title{
PRODUCTION AND CHARACTERIZATION OF MONOCLONAL ANTIBODIES AGAINST THE AVIAN INFECTIOUS BRONCHITIS VIRUS
}

${ }^{1}$ Doctor, Postgraduate Program in Biotechnology/UFPEL; ${ }^{2}$ Doctor, Professor, Veterinary MedicineGuaranhuns/UFRPE; ${ }^{3}$ Doctorate student, Postgraduate Program in Biotechnology/UFPEL; ${ }^{4}$ Doctor in Veterinary Sciences/UFRGS; ${ }^{5}$ Doctor, Professor/UPF; ${ }^{6}$ Doctor, Embrapa Swine and Poultry, Concórdia/SC; ${ }^{7}$ Doctor, Professor, Biotechnology Unit/CDTEC/UFPEL; ${ }^{8}$ Doctor, Professor, Biotechnology Unit and Nutrition Course/UFPEL.

\section{ABSTRACT}

T he use of monoclonal antibodies (MAbs) has contributed to the diagnosis of avian infectious bronchitis (IB), however their use are still limited because the utilized MAbs are imported, increasing the cost of such methodologies. Therefore, given the relevance of the national poultry production as well as the losses caused by the occurrence of IB in commercial poultry flocks, it is important that Brazil can produce biological supplies to use for diagnostic of IB. Thus, the present work reports the production, and characterization of MAbs against the infectious bronchitis virus (IBV). Two groups of three Balb-c female mice were inoculated with inactivated classic or variant IBV for 10 times, once per week. The splenocytes from mouse with higher serum concentration against IBV antigens were harvested and fused with murine Sp2/O-Ag14 myeloma cells. We generated two hybridomas secreting MAbs anti-IBV (MAb 2G4 and 5A11) from the fusion of myeloma cells and B-lymphocytes from a mouse immunized with the variant IBV. Following the characterization by ELISA and Western Blot, it was observed that MAbs recognize the IBV classic and variant types, showing more intense reactions with IBV variant. The MAbs obtained in this study have potential for use in immunodiagnostic for IB.

Keywords: Immunodiagnosis. Classic IBV. Variant IBV. Hybridoma. Coronavirus. 


\section{INTRODUCTION}

The avian infectious bronchitis is an acute and contagious disease, caused by a member of Coronavirus genus that affects Gallus gallus domesticus species (KING; CAVANAGH, 1991). The virus genome is surrounded mainly by three proteins: nucleoprotein $(N)$, matrix glycoproteins (M) and the spike (S), which is composed by two subunits, S1 and S2. There is also a protein that is associated to virus envelope (E) (McKINLEY et al., 2008).

The infectious bronchitis virus (IBV) infects manly the respiratory and urinary systems of chickens (KING; CAVANAGH, 1991; SANTOS et al., 2005), resulting in reduction of weight gain and egg production and quality (ARIYOSHI et al., 2010). The virus replication in respiratory tissue causes characteristic signals, as difficulty in breathing, cough, nasal discharge and produces specific injuries in the trachea, which is the selected organ for its replication (KING; CAVANAGH, 1991).

This disease is highly widespread among commercial poultry productions and it is one of the viral diseases that caused the most economic loss in poultry production. The losses occur because the retarded growth, decreased egg production and quality, mortality, condemnation of the slaughter and spending with diagnostic, vaccines and antimicrobial to treat secondary bacterial infections (CAVANAGH, 2007; MENDONÇA et al., 2009).

Therefore, the rapid detection and identification of the virus are necessary to take appropriate measures control. The conventional diagnosis methods of the IB are based on viral isolation in Specific Pathogen Free (SPF) embryonated chicken eggs or in mammalian cells culture, followed by antigenic identification. This methodology, besides being laborious, needs extreme biosecurity, and a long time to analyse, between seven to 10 days (GELB, 1989; OWEN et al., 1991).

Different immunological diagnostic methods have been developed, and most of them uses antisera against different parts of the virus or monoclonal antibodies (MAbs) raised against one or more virus epitopes. Due to MAbs binds to a unique IBV epitope, their use increases the reliability and potential of these methodologies (CHEN et al., 2011; IGNJATOVIC; ASHTON, 1996; WIT, 2000). 
Some research groups have been working to develop MAbs from virus antigen or recombinant proteins, but, due to a high genetic diversity of the IBV from different places, it is possible that an antibody produced against the IBV from one region cannot present the same sensibility to IBV from other region (CHEN et al., 2011; JONES, 2010). Besides, as there is not a specific MAb to IBV in Brazil, it have to be imported, what increases the cost of this methodologies, making them costly and sometimes inaccessible. Hence, in this context, the aim of this study was to produce MAbs using the whole virus as antigen, since viral epitopes are not easily expressed, and frequently, does not present the same conformation of the native epitope, affecting the antibody biding to viral antigen. In addition to the MAbs production, this study also aimed to characterize MAbs against IBV, in order to use it as immunodiagnostic tools to detect the presence of this virus.

\section{MATERIAL AND METHODS}

\section{Virus samples}

Two samples of IBV, previously isolated and characterized by PCR as classical and variant IBV were gently provided by Centro Nacional de Pesquisa em Suínos e Aves (CNPSA) from Empresa Brasileira de Pesquisa Agropecuária (Embrapa) - Concórdia - SC. Bouba virus and Newcastle disease virus were obtained by reformulation of commercial vaccines (Biovet ${ }^{\oplus}$ ). For viral antigen production, the virus was amplified in embryonated specific pathogen-free eggs and purified by ultracentrifugation.

\section{Mice immunizations}

All procedures with animals were performed according to the ethical principles of the Conselho Nacional de Controle de Experimentação Animal (CONCEA). For MAbs production, six-week-old female Balb/c mice (two groups with 3 mice each) were immunized 10 times with $100 \mu \mathrm{g}$ of classic IBV or variant IBV, by intra-peritoneal inoculation. In the first dose, the virus was emulsified in Complete Freund adjuvant and, the subsequently boosted (two weeks after the first and, weekly, after the second immunization) with Incomplete Freund adjuvant. One week after the last immunization, sera were collected and the antibody titer analysed by indirect ELISA using the variant IBV as antigen. 
Cell fusion was performed using the cells from the mouse with the highest antibody level against IBV. Three days before the cell fusion, the selected mouse received another IBV dose with incomplete adjuvant, by intra-peritoneal and a dose with only the IBV (100 $\mu \mathrm{g})$, by intravenous via.

\section{Cell fusion}

Hybridomas were obtained by mice splenocytes fused with myeloma cells (SP2/O-Ag14), and cultivated at $37^{\circ} \mathrm{C}$ in $\mathrm{CO}_{2}$ chamber according to Harlow and Lane (1988). Briefly, the mice spleen was macerated in incomplete DMEM (Dulbecco's Modified Eagle Medium, SigmaAldrich) without fetal bovine serum (FBS, Sigma-Aldrich), centrifuged at $1000 \times g$ for 8 minutes and the cells were resuspended in DMEM and centrifuged again. At the end of three centrifugations, the splenocytes were resuspended in $10 \mathrm{~mL}$ of incomplete DMEM. After, recovered spleen cells were mixed with approximately $4 \times 10^{7} \mathrm{SP} 2 / \mathrm{O}-\mathrm{Ag} 14$ cells and centrifuged at $1000 \times g$ for 8 minutes. The supernatant was discarded and the fusion was performed by the addition of $1 \mathrm{~mL}$ of $50 \%$ polyethylene glycol solution (PEG) during 1 minute, and then $9 \mathrm{~mL}$ of incomplete DMEM was added. Further, fused cells were centrifuged at $1000 \times g$ for 10 minutes, and resuspended in $50 \mathrm{~mL}$ of DMEM containing hypoxanthine $\left(1 \times 10^{-6} \mathrm{M}\right)$, aminopterin $\left(4 \times 10^{-9} \mathrm{M}\right)$, thymidine $\left(1.6 \times 10^{-7} \mathrm{M}\right)$ (HAT, SigmaAldrich) and $20 \%$ of fetal bovine serum. The fused cells were distributed into 96 -wells cell culture plates $\left(0.1 \mathrm{~mL} /\right.$ well). Plates were incubated at $37^{\circ} \mathrm{C}$ in a $5 \% \mathrm{CO}_{2}$ atmosphere.

The selection of MAb-secreting hybridomas was performed by indirect ELISA using as antigen both classic and variant IBV. The positive hybridoma were cloned twice by limiting dilution, retested, expanded and stored in liquid nitrogen or injected in mice to ascites fluid production.

\section{Ascites production and MAbs purification}

Mice (BALB/c) six-week-old were intraperitoneally sensitised with $0.5 \mathrm{~mL}$ of Pristane $(2,6$, 10, 14-tetramethyl-pentadecane, Sigma), and after 10 days, $5 \times 10^{6}$ cells of hybridomes were intraperitoneally inoculated into mice. After approximately 14 days, mice were punctured to obtain the ascites fluid which was centrifuged at $1500 \times g$ for 10 minutes. 
MAbs were purified by protein A column, according to the manufacturer's instructions (Amersham, MS) and the MAbs concentration was determinated by $280 \mathrm{~nm}$ absorbance and calculated based on extinction coefficient.

\section{MAbs characterization}

MAbs sensibility and specificity was evaluated by indirect ELISA and Western Blot. By indirect ELISA, the classic and variant IBV, Bouba and Newcastle disease virus were tested. Briefly, 96-wells plates (Polysorp, NUNC ${ }^{\circledR}$ ) were coated with $100 \mu \mathrm{L}$ of $250 \mathrm{ng}$ per well of each antigen in $0.05 \mathrm{M}$ Carbonate-Bicarbonate ( $\mathrm{pH} 9.6)$ and incubated at $4{ }^{\circ} \mathrm{C}$ overnight. After, the wells were washed 3 times with PBS-T (Tween 20 at 0.05\%) and incubated with purified MAbs (diluted 1:200 in PBS-T) for one hour at $37{ }^{\circ} \mathrm{C}$. As positive control, immune sera collected before the cell fusion (1:12800) were used and, as negative control, the pre immune sera (1:200) were used. After 3 washes with PBS-T, wells were incubated with antimouse peroxidase conjugated antibody diluted $1: 4000$ for one hour at $37^{\circ} \mathrm{C}$. Following, after 3 washes with PBS-T the wells were incubated with $100 \mu \mathrm{L}$ of substrate (orthophenylenediamine + Citrate Phosphate $+\mathrm{H}_{2} \mathrm{O}_{2}$ ). Then, the plates were incubated in a dark room for 15 minutes. The assays were read at an absorbance of $450 \mathrm{~nm}$.

To evaluate the main viral epitopes recognised by MAbs, classic and variant IBV samples (450 $\mu \mathrm{g})$ were added to buffer with reduction ( $2 \beta$-mercaptoethanol), submitted to SDS-PAGE $8 \%$ and transferred to a nitrocellulose membrane (90 minutes at $80 \mathrm{~W})$. After transferring the proteins, the membrane was blocked with $5 \%$ skimmed milk in PBS, and then, the MAbs (diluted 1:200 in PBS-T) were added and the membrane was incubated for $1 \mathrm{~h}$. Then, the membrane was incubated for $1 \mathrm{~h}$ with anti-mouse peroxidase conjugated antibody diluted 1:4000 in PBS-T. The antigen-antibody reaction was performed by addition of a substrate containing diaminobenzidine tetrahydrochloride (DAB). All reactions were developed at room temperature and after each step the membrane was washed 3 times with PBS-T.

\section{Statistic analysis}

Humoral immune responses were analysed by GraphPadPrism5 (GraphPad Software), using ANOVA and Tukey test (Tukey Significant Difference). 


\section{RESULTS AND DISCUSSION}

MAbs were produced using cells from the mouse immunized with the variant strain because it presented the highest antibody levels with both antigens (classic and variant IBV). Another factor that contributed to the choice of the animal immunized with variant IBV for the MAbs production was the increase of incidence of the variant IBV, including Brazilian genotypes, which are different from those described in other countries (ABREU et al., 2006; D'ARCE et al., 2008; MONTASSIER et al., 2006; VILLARREAL et al., 2007).

Overall, it is necessary a diagnostic method sensible to new variants, which could not have been achieved if the MAbs were produced by a classic IBV immunized animal, because, little differences in the IBV antigens could forbid MAbs to recognise variants strains.

After lymphocytes B from immunized mice with variant IBV and myeloma cells (SP2) fusion, culture, selection and cloning steps, two hybridomas secreting anti-IBV MAbs, called 2G4 and $5 A 11$ were obtained. MAbs ability to recognise the classic and variant IBV and theirs specificity facing others avian viruses were determinated.

The characterization of the two MAbs (2G4 and 5A11) regarding their capacity to recognise the native IBV by indirect ELISA, showed a high reaction between MAbs and variant IBV, with mean absorbance of 0,8 . However, when tested with classic IBV, both MAbs presented significant decreasing $(p<0.05)$ (Figure 1) Thus, these data suggest that the MAbs are more specific to variant IBV than to the classic IBV.

Furthermore, immunized mice sera, collected before cell fusion, used as positive control, showed higher reaction than MAbs, not only in test with variant IBV but also with classic IBV $(p<0.05)$ (Figure 1). Besides, pre-immune mice sera, used as negative control, did not react with any antigen tested.

Western Blot results agreed with ELISA. Notably, the two MAbs strongly recognised variant IBV, suggesting again more specificity to this strain, and both recognised, but with less intensity, the classic IBV.

The absorbance reactions of both MAbs were, in general, similar. Nevertheless, as showed in Figure 1, the MAb 5A11 presented higher absorbance with the variant IBV and lower 
absorbance with classic IBV, suggesting that it has more specificity than the other MAb (2G4). Western Blot results also suggest higher specificity to MAb 5A11 (Figure 2).

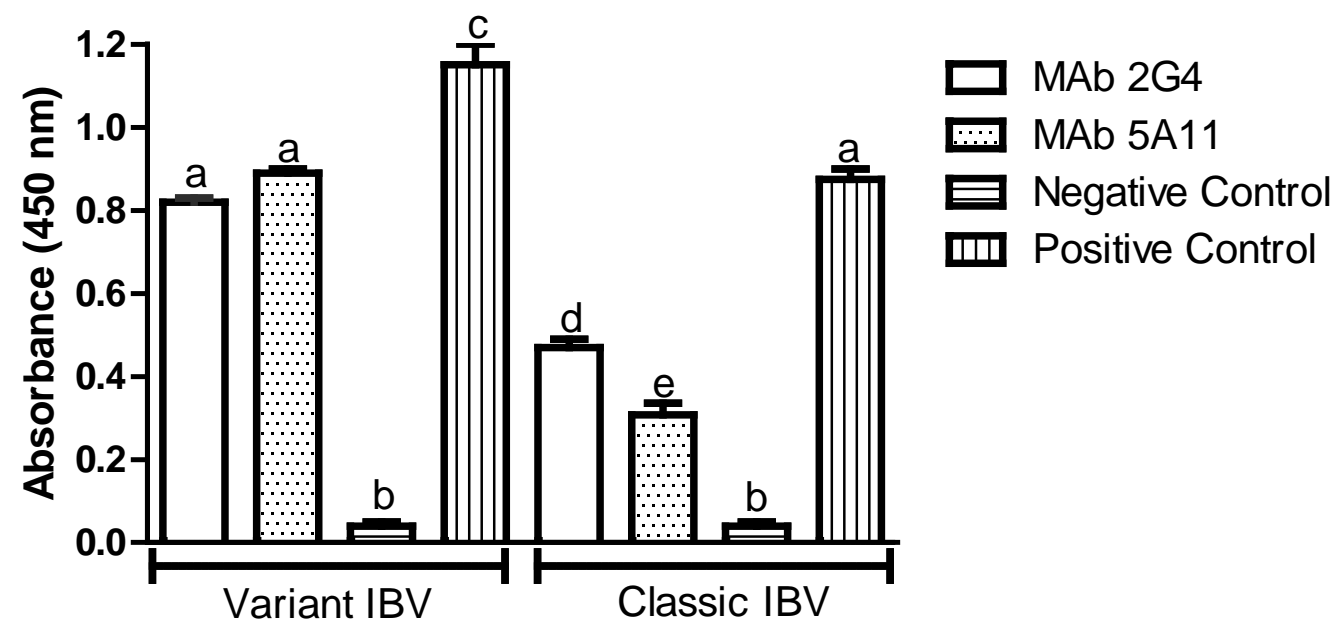

Figure 1 - Reactivity of MAbs anti-IBV (2G4 and 5A11) obtained from a mouse immunized with the variant IBV, against classic and variant IBV by indirect ELISA. Sera from immunized mice were used as positive control and pre immune sera were used as negative control. Values showed the triplicates mean absorbance $(450 \mathrm{~nm})$ and different letters present statistic difference using ANOVA and Tukey test (Tukey Significant Difference) $(p<0,05)$.

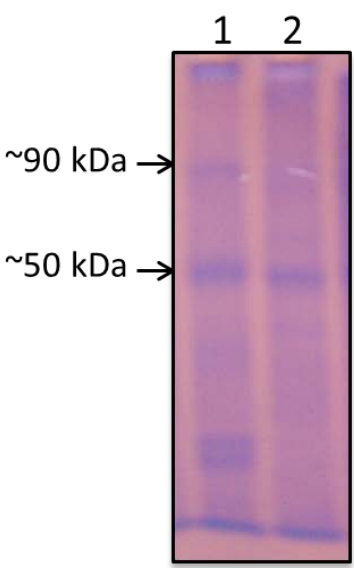

A

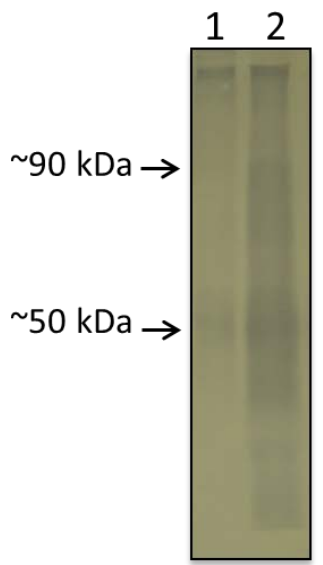

B

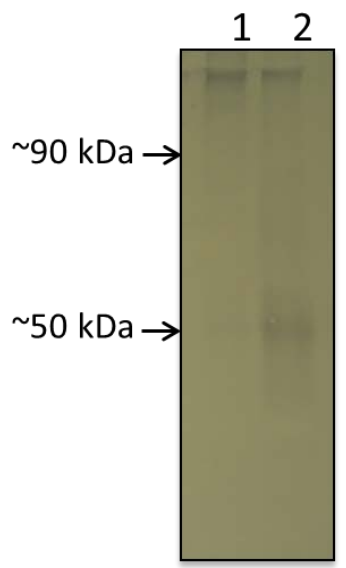

C

Figure 2 - Reactivity of MAbs anti-IBV (2G4 and 5A11) obtained from a mouse immunized with the variant IBV, against variant and classic IBV by Western Blot. A) SDS PAGE 8\% stained with Coomassie Blue; B) Western Blot using the MAb 2G4; C) Western Blot using the MAb 5A11. 1. Classic IBV; 2. Variant IBV. The SDS-PAGE (A) shows the viral proteins profile with two specific bands with $\sim 90 \mathrm{kDa}$ and $\sim 50 \mathrm{kDa}$, the same bands are recognized by MAbs in Western Blot (B and C). 
The specificity of MAbs in recognising only IBV was evaluated with other avian viruses: Bouba and Newcastle disease virus. The reactions are significantly lower compared to variant IBV. These initial characterization results of MAbs $2 \mathrm{G} 4$ and $5 \mathrm{~A} 11$ suggests that the MAbs obtained in the present study have potential to be used as a tool for use in immunodiagnostic tests to IB, as immunohistochemistry and ELISA.

The immunohistochemistry technique detects antigens on the tissue using antibody (PAbs or MAbs), being the affinity, sensibility and specificity determinant factors to the technique effectiveness. This technique brings various benefits to a fast diagnostic, since it does not require the viral isolation process and the antigen can be directly detected from infected avian tissue. Besides the immunohistochemistry technique application, the MAbs show potential as a tool for diagnostic in other antigen-antibody reaction based tests, such as capture ELISA (IGNJATOVIC; MCWATERS, 1991; NAQI et al., 1993) and blocking ELISA (CHEN et al., 2011; KARACA; NAQI, 1993).

\section{CONCLUSION}

MAbs 2G4 and 5A11, produced in this study, recognised specifically IBV. Hence, both MAbs present potential to be used in serological diagnosis of IB. Moreover, the MAbs can be used to monitor the mutations in IBV.

\section{PRODUÇÃO E CARACTERIZAÇÃO DE ANTICORPOS MONOCLONAIS CONTRA O VÍRUS DA BRONQUITE INFECCIOSA DAS GALINHAS}

\section{RESUMO}

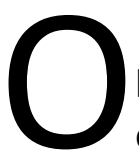

uso de anticorpos monoclonais (AcMs) tem colaborado e facilitado o diagnóstico da bronquite infecciosa das galinhas (BI), porém, seu uso no Brasil ainda é limitado, pois os AcMs utilizados são importados, elevando o custo de tais metodologias, por isso, dada a relevância da produção avícola nacional bem como os prejuízos causados pela ocorrência da BI nos plantéis avícolas comerciais é importante que o Brasil seja capaz de produzir insumos biológicos que possam ser utilizados para a realização do diagnóstico de tal enfermidade. Dessa forma, o presente trabalho relata a produção e caracterização de AcMs contra o vírus da bronquite infecciosa das galinhas (VBI). Dois grupos contendo três camundongos fêmeas foram inoculados 10 vezes, semanalmente, com VBI clássico ou variante semanalmente. $\mathrm{O}$ camundongo com níveis de anticorpos mais altos foi utilizado 
para a fusão celular dos esplenócitos com células de mieloma (Sp2/O-Ag14). Foram obtidos dois hibridomas secretores de AcMs anti-VBI a partir da fusão entre os linfócitos B de um camundongo imunizado com o $\mathrm{VBI}$ variante e células de mieloma. Foi observado, na caracterização por ELISA indireto e Western Blot, que os AcMs reconhecem as cepas de VBI clássico e variante, sendo as reações com as cepas variantes mais intensas. Os AcMs obtidos neste estudo apresentam potencial para uso no imunodiagnóstico para BI.

Palavras-chave: Imunodiagnóstico. VBI clássico. VBI variante. Hibridoma. Coronavírus.

\section{PRODUCCIÓN Y CARACTERIZACIÓN DE LOS ANTICUERPOS MONOCLONALES CONTRA EL VIRUS DE LA BRONQUITIS INFECCIOSA AVIAR}

\section{RESUMEN}

5 I uso de anticuerpos monoclonales (MAbs) ha colaborado y facilitado el diagnóstico de la bronquitis infecciosa (BI), pero su uso en Brasil aún es limitado debido a que los anticuerpos monoclonales utilizados son importados, elevando el costo de tales métodos. Dada la relevancia de la producción nacional de aves de corral, así como los daños causados por la ocurrencia de BI en planteles comerciales de aves de corral, es importante que Brasil sea capaz de producir insumos biológicos que puedan ser utilizados para el diagnóstico de esta enfermedad. Por lo tanto, este documento informa de la producción, caracterización y aplicación de anticuerpos monoclonales contra el virus de la bronquitis infecciosa (IBV). Fueron obtenidos dos hibridomas secretores de MAbs anti-IBV mediante la fusión de linfocitos $B$ de un ratón inmunizado con el IBV variante y células de mieloma. Fue observado, en la caracterización por ELISA y con Western blot, que estos MAbs reconocen las cepas clásicas de IBV y la variante, siendo la reacción más intensa con las cepas variantes. Los MAbs obtenidos en este estudio tienen potencial para su uso en inmunodiagnóstico para BI.

Palabras clave: Inmunodiagnóstico. IBV clásico. IBV variante. Hibridoma. Coronavirus.

\section{ACKNOWLEDGMENTS}

We are grateful to Coordenação de Aperfeiçoamento de Pessoal de Nível Superior (CAPES), Conselho Nacional de Desenvolvimento Científico e Tecnológico (CNPq) and Centro Nacional de Pesquisa em Suínos e Aves (CNPSA) of Empresa Brasileira de Pesquisa Agropecuária (Embrapa) to support. 


\section{REFERENCES}

ABREU, J. T.; RESENDE, J. S.; FLATSCHART, R. B.; et al. Genotipificação de isolados do vírus da bronquite infecciosa das galinhas (IBV) pelo sequenciamento de parte de $\mathrm{S} 2$ e do segmento de S1. Revista Brasileira de Ciência Avícola, supl. 8, p. 210, 2006.

ARIYOSHI, R.; KAWAI, T.; HONDA, T.; TOKIYOSHI, S. Classification of IBV S1 Genotypes by Direct Reverse Transcriptase-Polymerase Chain Reaction (RT-PCR) and Relationship between Serotypes and Genotypes of Strains Isolated between 1998 and 2008 in Japan. Journal of Veterinary Medical Science, v. 72, n. 6, p. 687-692, 2010.

CAVANAGH, D. Coronavirus avian infectious bronchitis virus. Veterinary Research, v. 38, p. 281-297, 2007. Available from: <http://dx.doi.org/10.1051/vetres:2006055>. Accessed: 12 feb. 2014. doi: 10.1051/vetres:2006055.

CHEN, H. W.; WANG, C. H.; CHENG, I. C. A type-specific blocking ELISA for the detection of infectious bronchitis virus antibody. Journal of Virological Methods, v. 173, n. 1, p. 7-12, 2011. doi: 10.1016/j.jviromet.2010.12.016.

D'ARCE, R. C. F.; FERREIRA, H. L.; TOLEDO, C. M.; et al. Ausência de similaridade entre sequências genômicas de amostras de campo e vacinais do vírus da bronquite infecciosa no Brasil. Revista Brasileira de Ciência Avícola, supl. 7, p. 215, 2008.

GELB, J. Jr. Infectious Bronchitis. In: PURCHASE, H. G. A laboratory manual for the isolation and identification of avian pathogens. 3. ed. Dubuque, lowa: Hunt Pub. Co. p. 124-127, 1989.

HARLOW, E.; LANE, D. Antibodies: A Laboratory Manual. New York: Cold Spring Harbor Laboratory, p. 726, 1988.

IGNJATOVIC, E. J.; ASHTON, F. Detection and differentiation of avian infectious bronchitis viruses using a monoclonal antibody-based, Avian Pathology, v. 25, n. 4, p. 721-736, 1996. doi: 10.1080/03079459608419177.

IGNJATOVIC, J.; MCWATERS, P. G. Monoclonal antibodies to three structural proteins of avian infectious bronchitis virus: characterization of epitopes and antigenic differentiation of Australian strains. Journal of General Virology, v. 72, p. 2915-2922, 1991.

JONES, R. C. Viral respiratory diseases (ILT, aMPV infections, IB): are they ever under control? British Poultry Science., v. 51, n. 1, p. 1-11, 2010.

KARACA, K.; NAQI, S. A monoclonal antibody-based ELISA to detect serotype-specific infectious bronchitis virus antibodies. Veterinary Microbiology, v. 34, n. 3, p. 249-257, 1993. 
KING, D. J; CAVANAGH, D. Infectious Bronchitis. In: SWAYNE, D. E. Diseases of Poultry. 9. ed. Ames: lowa State University Press, p. 471-484, 1991.

MCKINLEY, E. T.; HILT, D. A.; JACKWOOD, M. W. Avian coronavirus infectious bronchitis attenuated live vaccines undergo selection of subpopulations and mutations following vaccination. Vaccine, v. 26, n. 10, p. 1274-1284, 2008. Available from:

<http://dx.doi.org/10.1016/j.vaccine.2008.01.006>. Accessed: 05 mar. 2015. doi: 10.1016/j.vaccine.2008.01.006.

MENDONÇA, J. F. P.; MARTINS, N. R. S.; CARVALHO, L. B.; et al. Bronquite infecciosa das galinhas: conhecimentos atuais, cepas e vacinas no Brasil. Ciência Rural, v. 39, n. 8, p. 25592566, 2009. Available from: <http://dx.doi.org/10.1590/S0103-84782009005000195>. Accessed: 18 set. 2012. doi: 10.1590/S0103-84782009005000195.

MONTASSIER, M. F. S.; MORGAN, V. C.; BRENTANO, L.; et al. Diversidade do gene da glicoproteína S1 de estirpes do vírus da bronquite infecciosa isoladas no Brasil. Revista Brasileira de Ciência Avícola, v. 8, p. 221, 2006.

NAQI, S. A.; KARACA, K.; BAUMAN, B. A monoclonal antibody-based antigen capture enzyme-linked immunosorbent assay for identification of infectious bronchitis virus serotypes. Avian Pathology, v. 22, n. 3, p. 555-564, 1993.

OWEN, R. L.; COWEN, B. S.; HATTEL, A. L.; et al. Detection of viral antigen following exposure of one-day-old chickens to the Holland 52 strain of infectious bronchitis virus. Avian Pathology, v. 20, n. 4, p. 663-673, 1991. doi: 10.1080/03079459108418805.

SANTOS, B. M.; FARIA, J. E.; RIBEIRO, V. V. Doenças virais de importância nas aves. 2. ed. Viçosa: EDUFV, 2005. 71p.

VILLARREAL, L. Y. B.; BRANDÃO, P. E.; CHACÓN, J. L.; et al. Molecular characterization of infectious bronchitis virus strains isolated from the enteric contents of Brazilian laying hens and broilers. Avian Diseases, v. 51, n. 4, p. 974-978, 2007. doi: 10.1637/7983-041307.1.

WIT, J. J. Detection of Infectious Bronchitis Virus. Avian Pathology, v. 29, n. 2, p. 71-93, 2000. doi: 10.1080/03079450094108. 